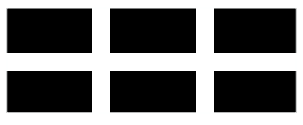

ThE WILliAM DAVIDSON INSTITUTE AT THE UNIVERSITY OF MICHIGAN BUSINESS SCHOOL

\title{
Votes and Vetoes: The Political Determinants of Commercial Openness
}

By: Witold J. Henisz and Edward D. Mansfield

William Davidson Institute Working Paper Number 712

July 2004 


\title{
Votes and Vetoes: The Political Determinants of Commercial Openness
}

\author{
Witold J. Henisz \\ The Wharton School \\ University of Pennsylvania \\ 2021 Steinberg Hall - Dietrich Hall \\ Philadelphia, PA 19104-6370 \\ henisz@wharton.upenn.edu
}

Edward D. Mansfield

Department of Political Science

University of Pennsylvania

223 Stiteler Hall

208 S. $37^{\text {th }}$ Street

Philadelphia, PA 19104-6215

emansfie@sas.upenn.edu

April 25, 2004 


\title{
Votes and Vetoes: The Political Determinants of Commercial Openness
}

\begin{abstract}
$\underline{\text { Abstract }}$
Societal theories of trade policy stress the importance of domestic interest groups, whereas statist theories focus on the effects of domestic institutions. Debates over the relative merits of these approaches have been fierce, but little systematic empirical research has been brought to bear on the relative merits of these theories. In this paper, we argue that, while societal and statist factors are generally regarded as having independent and competing effects, it is more fruitful to view the influence of each type of factor as conditional on the other. As societal explanations contend, deteriorating macroeconomic conditions are a potent source of protectionist pressures. The extent to which such conditions reduce commercial openness, however, depends centrally on the domestic institutions through which societal pressures must filter to influence policy.

Two institutional features stand out. First, in states marked by greater fragmentation and more "veto points," it is harder to change existing policies because any number of actors can block such change. Consequently, we expect the effects of macroeconomic conditions on trade policy to be weaker in fragmented states than in those characterized by a highly centralized national government. Second, we expect both fragmentation and the societal pressures stemming from the economy to have a more potent impact on trade policy in democracies than in other regimes, since the electoral constraints facing democratic leaders force them to respond to demands made by key segments of society. The results of our statistical tests covering more than one hundred countries during the period from 1980 to 2000 strongly support these arguments.
\end{abstract}

Keywords: Protectionism, openness, veto players, veto points, positive political theory, unemployment, trade

JEL Classifications: F13, P16, P26 


\section{$\underline{\text { Introduction }}$}

Much of the recent literature on the political economy of trade policy emphasizes the role of domestic politics. Societal theories of foreign economic policy stress the importance of domestic interest groups, whereas statist theories focus on the effects of domestic institutions. Debates over the relative merits of these approaches have been fierce, but little systematic empirical research has been brought to bear on the relative merits of these theories. Moreover, most extant research addresses trade policy in stable, mature and wealthy democracies, a tack that places important restrictions on the range of both interest group pressures and domestic political institutions that are analyzed and thereby hampers efforts to assess the usefulness of each approach.

In this paper, we analyze the domestic determinants of commercial openness for democracies and non-democracies at all stages of economic development. Our core argument is that, while societal and statist factors are generally regarded as having independent and competing effects, it is more fruitful to view the influence of each type of factor as conditional on the other. More specifically, as societal explanations contend, deteriorating macroeconomic conditions are a potent source of protectionist sentiment in society. The extent to which such conditions reduce commercial openness, however, depends centrally on the domestic political institutions through which societal pressures must filter to influence policy.

Two institutional features stand out. First, countries vary substantially in the degree to which authority is concentrated within the national government. In states marked by greater fragmentation and more "veto points," it is harder to change existing policies because any number of actors can block such change. Consequently, we expect the effects of macroeconomic conditions on trade policy to be weaker in fragmented states than in those characterized by a highly centralized national government. Second, we expect both fragmentation and the societal pressures stemming from the economy to have a more potent impact on commercial openness in democracies than in other regimes. The electoral constraints facing democratic leaders force them to respond to demands made by key segments of society. While autocrats can more easily change policies than democratic leaders, regardless of how concentrated power is in a democracy, autocrats depend on a narrower set of groups for political power than their democratic counterparts. This set of groups is less likely to base their political support on broad 
macroeconomic conditions than on whether they benefit from the government's economic policy, regardless of the economy's overall performance.

Taken as a whole, we therefore expect deteriorating macroeconomic conditions to impede commercial openness; but the effect of these conditions is likely hinge on the extent of institutional fragmentation. Equally, we expect macroeconomic factors to have a more pronounced influence on trade policy in democracies than other countries. The results of our statistical tests covering more than one hundred countries during the period from 1980 to 2000 strongly support these arguments.

\section{Societal Interests, Political Institutions, and Trade Policy}

Various studies of trade policy emphasize the role of groups within society. ${ }^{1}$ Societal theories focus on how interests groups affect trade policy through demands made on public officials. Such explanations view trade policy as the outcome of competition among coalitions with an interest in foreign commerce. Domestic institutions and policy makers are considered passive actors that supply the trade policies demanded by the most influential portions of society (Ikenberry, Lake, and Mastanduno 1988).

Societal theories frequently infer demands for protection from macroeconomic conditions, contributing to a burgeoning literature has emerged on the links between aspects of national economic performance and foreign commerce (e.g., Baldwin 1989; Bergsten and Cline 1983; Bhagwati 1991; Bohara and Kaempfer 1991; Cline 1989; Corden 1993; Deardorff and Stern 1987; Destler 1992; Dornbusch and Frankel 1987; Gardner and Kimbrough 1989; Magee, Brock, and Young 1989). These theories argue that policy makers have reason to respond to demands for protection arising from broad segments of the populace. There is considerable evidence that voters pay attention to overall macroeconomic conditions as well as their own economic circumstances when casting ballots (Colton 2000; Kinder and Kiewiet 1981; LewisBeck 1988). Furthermore, survey research indicates that public support for protectionism rises as domestic economic conditions deteriorate (Shapiro and Page 1994). Government officials therefore have reason to raise trade barriers when these conditions worsen in an effort to bolster their prospects of retaining office.

\footnotetext{
${ }^{1}$ The classic statement is Schattschneider (1935).
} 
It is widely argued that, among the macroeconomic determinants of trade policy, unemployment is crucial. In fact, as C. Fred Bergsten and William R. Cline (1983: 77) point out, "conventional wisdom suggests that high levels of unemployment are the single most important source of protectionist pressures." Similarly, an International Monetary Fund study concludes that "perhaps the most crucial factor - and the one most likely to influence policy choices toward protection - is the extent and duration of existing unemployment" (Nowzad 1978: 35). Various studies have arrived at the same conclusion (Hughes and Waelbroeck 1981; Wallerstein 1987).

Heightened unemployment is expected to generate calls for protectionism by making it more difficult for workers to adjust to increases in imports. Workers who lose their jobs due to rising import competition will find it harder to find alternative employment and are likely to be paid less once they become reemployed. These workers and others who fear that they may soon become unemployed have reason to press for relief from foreign competition (Bradford 2003). So do firms that depend on consumption by these workers. A surge in unemployment serves as a focusing event that stimulates workers, investors, and other interest groups adversely affected by open trade to overcome collective action problems and mobilize for protection (Olson 1983).

Whereas societal approaches point to the importance of influential segments of society in determining trade policy, they give short shrift to the domestic political institutions that filter societal demands and set policy. Crucial in this regard are the extent of fragmentation within a country's national government and its regime type.

The fragmentation of power within a government depends on the number of independent partisan and institutional actors whose agreement is necessary to make policy. These actors include competing branches of government and coalitions within a given branch. As the number of independent actors with such veto power - or veto points - increases, societal groups have greater difficulty pressing for a change in policy (Henisz 2000; Tsebelis 2003). Scholars working in the field of positive political theory have identified veto points as one of the most important institutional elements of policymaking (McCubbins, Noll, and Weingast 1987, 1989; Tsebelis 2003; Wade 1990; Weingast and Moran 1983).

In our context, any single actor with the authority to set trade policy understands that the final policy outcome must lie within a range of policies that satisfies all veto points. To the extent that the preferences of the actors with veto power differ, institutional structures with more veto points limit the range of feasible trade policy choices. As a result, "the potential for policy 
change decreases with the number of veto players, the lack of congruence (dissimilarity of policy positions among veto players) and the cohesion (similarity of policy positions among the constituent units of each veto player) of these players" (Tsebelis 1995: 289).

Several cross-national empirical studies that link policy stability to the number of veto points support these theoretical insights. Hallerberg and Basinger (1998), for example, find that in response to tax cuts enacted by the United States in the 1980s, members of the Organization for Economic Cooperation and Development with fewer de facto veto points lowered their tax rates by a greater amount than did countries with more checks and balances. Analyzing longer term processes, Franzese (1999) and Treisman (2000) conclude that countries with more veto points have more stable (either high or low) government deficits and inflation rates, respectively. Haggard and Kaufman (1995) maintain that fragmented power within a government creates impediments to initiating and sustaining economic reform. MacIntyre (2001) reports that a nonlinear relationship exists between veto points and policy responses to the 1997 East Asian financial crisis: too many veto points generate overly rigid policies and inhibit policy change during economic crises whereas too few veto players lead to arbitrary or capricious changes in policy rather than a negotiated compromise. Milner (1997) argues that it becomes increasingly difficult to forge international economic agreements as the number of veto points rises in prospective participants.

Relatively few studies have addressed the effects of veto points on trade policy. But Lohmann and O'Halloran (1994) find that divided government has impeded trade liberalization by the United States. Unified government, by contrast, has reduced the effective number of veto points and promoted liberalization. In a study of post-communist countries during the 1990s, however, Frye and Mansfield (2003) find that trade reform grows more likely as the number of veto players increase, especially in non-democratic states. This result, they argue, stems from the autarkic trade regimes put in place by these countries during the Cold War and the tendency for an increase in the number of veto players after the collapse of the Berlin Wall to expand the range of economic interests shaping foreign economic policy, bringing groups with an interest in trade liberalization on to the political stage and leading to more open overseas commerce.

The difference between the effects of veto points in these two studies may be an outgrowth of variations in the status quo policy that the authors consider. In the situation analyzed by Lohmann and O'Halloran (1994), the status quo trade policy is relatively open and 
was developed by a comparable set of political actors to those currently holding power. A reduction in the number of veto players thus allows a subset of political actors to overcome opposition and push through a change in the status quo policy, leading to trade liberalization. In the case of post-communist countries, by contrast, the status quo trade policy is highly protectionist and nations differ substantially in the extent to which the existing political actors and veto players are the same as or closely related to those that promoted closure. Where veto players are more numerous, political regime change has brought new political actors to the table, fostering a new trade liberalization coalition. Where few veto players exist, it is more likely that the same political actors that supported autarky remain in power. This interpretation of these conflicting findings highlights the need to control for the status quo trade policy and to explore the impact of the nature of the political regime and any changes therein.

\section{$\underline{\text { Regime Type and Trade Policy }}$}

Our analysis adds to the burgeoning literature on the political economy of foreign trade by addressing the combined effects of societal pressure generated by macroeconomic conditions and institutional fragmentation on political actors' incentives to change trade policy. Consistent with societal theories, heightened unemployment will stimulate interest group demands for policies to reduce unemployment at the expense of cheaper imports, including reductions in commercial openness. Consistent with the literature on positive political theory, however, we also argue that that by constraining the behavior of political actors, policymaking structures with more fragmentation reduce the sensitivity of political actors to such societal pressures. When a large number of veto players exist, there is likely to be some player that is hostile to raising trade barriers and can frustrate societal demands for protection. As the number of veto players decline, it becomes easier to change the existing trade regime since these actors are more likely to have relatively homogeneous interests (Henisz 2000). We therefore anticipate that adverse macroeconomic conditions should lead to a larger decline in external trade linkages as countries become more institutionally centralized.

Of course, the need for leaders to respond to such demands differs markedly depending on whether the populace is able to monitor their behavior and penalize them for being unresponsive. In democracies, the populace is able to do so. Indeed, the hallmark of democracy 
is the existence of regular, open, and fair elections involving candidates who compete for the votes of a large portion of the adult population (e.g., Huntington 1991: 5-13; Przeworski et al. 2000; Schumpeter 1942). Furthermore, a free press and the relatively free flow of information about governmental activities keep constituents apprised of changes in foreign economic policy and leaders' activities. If democratic leaders do not take overt steps to cushion the effects of macroeconomic downturns - including an increase in trade barriers - they face the prospects of being turned out of office by voters.

Non-democratic governments, by contrast, are less susceptible to broad-based societal demands. The absence of electoral pressures and checks on their power by an independent and representative legislature give non-democratic leaders less incentive to respond to demands for protection arising from heightened unemployment than their democratic counterparts. Like democratic leaders, autocrats rely on the support of various interest groups to maintain power. However, the segment of society to which an autocrat must appeal to retain office is typically much narrower and therefore less motivated by aggregate macroeconomic conditions than in a democracy. Instead, an autocrat's key constituents tend to focus greater attention on how resources are distributed within society and their share of these resources rather than national economic performance. As a result, despite the absence of veto players, autocrats should also be less sensitive to the societal pressures generated by adverse macroeconomic conditions (Acemoglu and Robinson 2003; Brooker 2000; Wintrobe 1998).

In sum, then, we expect commercial openness to dip as the level of unemployment rises, and we anticipate that the influence of unemployment will grow larger as the number of veto players decline. In addition, while democracies are generally marked by a higher number of veto players than non-democracies, we expect the impact of unemployment and veto players to be more pronounced in democratic regimes. ${ }^{2}$

Anecdotal evidence points to the role that veto players can exert on trade policy. Consider the cases of Chile and Peru. In Chile a democratically-elected government came to power in 1989 and subsequently cut tariffs to 11 percent in 1991 (Lederman 2001: 226-27).

\footnotetext{
${ }^{2}$ It is important to recognize that regime type and veto points tap different, although somewhat related, aspects of domestic politics. The extent of veto points varies quite a bit among democracies and non-democracies alike (the mean among stable democracies is 0.60 and the standard deviation is 0.26 while among other nations the mean is 0.09 and the standard deviation 0.20 ). Furthermore, while democracies tend to have more veto points than other countries, the correlation between regime type and veto points is not overwhelmingly high ( 0.63 or 0.46 , depending on which measure of veto points is analyzed; see Table 1).
} 
Based on our data, the number of veto players in Chile rose during the early 1990s. Consistent with our argument, the Chilean government succeeded in warding off demands for protection during this decade. As Saez, Salazar, and Vicuña (1995: 49) point out, in the early 1990s, the government faced "pressures to raise the level of protection" but "these pressures were not fruitful." Nor were such pressures effective at the end of this decade, despite an unemployment rate that rose to almost 10 percent (Lederman 2001). Again, Chile's maintenance of its status quo open trade policy accords with our claim that deteriorating macroeconomic conditions are less likely to yield heightened trade barriers in democracies with more extensive veto points.

In Peru's emerging democracy, rising unemployment during the early 1980s reached a rate of about 60 percent by 1984. At the same time, Wise (1989: 170) reports that, due to constitutional changes and other developments, there was "greater concentration of power in the executive." As such, the number of veto players declined during the first half of the 1980s. Hence, it is not surprising that Peru abandoned its export-led growth strategy and increased trade barriers during these years (Nogues and Gulati 1994: 487; Wise 1989: 170). We would expect that demands for protection spurred by heightened unemployment would have a greater effect on trade policy as the number of veto players declines.

Of course these are only illustrations of our argument. But they suggest that the factors we emphasize have influenced trade policy. To more fully test our argument, we now turn to a set of quantitative analyses. These analyses depart from the empirical work on the domestic politics of trade policy in various ways. First, very few studies have addressed the effects of political fragmentation on trade policy; none that we are aware of have addressed how fragmentation influences the relationship between societal factors and foreign commerce. In fact, while it is widely recognized that institutional and societal factors are likely to have an interactive effect on trade policy, little research has explicitly considered this issue (Gilligan 1997; Mansfield and Busch 1995; Milner 1997). Instead, most empirical studies posit that societal demands and policy structures operate independently of each other. Our model, by contrast, explicitly accounts for the intervening role of policymaking structures and political regimes. Second, the vast bulk of the empirical studies of trade policy have focused on democratic, advanced industrial countries. Although there has been widespread interest in whether variations in regime type are linked to patterns of commercial openness, systematic research on this topic has been relatively scarce (Frye and Mansfield 2003; Mansfield, Milner, 
and Rosendorff 2000, 2002; Milner and Kubota forthcoming). Equally, the work that has been conducted has not addressed whether the societal influences on trade policy vary between democracies and non-democracies. Our analysis - covering over one hundred countries between 1980 and 2000 - will provide some of the first quantitative results bearing on this important issue.

\section{$\underline{\text { Model and Measures }}$}

To test our argument, we begin by estimating the following model:

$$
\begin{aligned}
& { }_{\text {IMPORTS }} \text { IM,t }_{1} \beta_{1} \text { NNEMPL }_{i, t-1}+\beta_{2} \text { POLCON }_{i, t-1}+\beta_{3} \text { UNEMPL }_{i, t-1} * \text { POLCON }_{i, t-1}+ \\
& \beta_{5} \text { IMPORTS }_{i, t-1}+\beta_{6} \text { REER }_{i, t-1}+\beta_{7} \Delta R E E R_{i, t-1}+\beta_{8} \Delta T O T_{i, t-1}+\beta_{9} \text { RES }_{i, t-1}+\beta_{10} \text { GPCF }_{i, t-1}+ \\
& \operatorname{PTA}_{i, t-1} \beta+\operatorname{COUNTRY}_{i} \beta+\operatorname{YEAR}_{t} \beta+\varepsilon_{i, t}
\end{aligned}
$$

Our dependent variable is the annual percentage change in import penetration. For each country, $i$, import penetration is defined as the value of imports in domestic currency divided by the nation's gross domestic product (GDP) in a given year $(t)$, using data drawn from the World Bank's World Development Indicators. The dependent variable is the percentage change in import penetration from year $t$-1 to year $t$. We have compiled data on this variable for 176 countries from 1980 to 2000 . The mean value of the dependent variable is two percent with a standard deviation of 22 percent, indicating both a slight tendency for countries to expand their imports over time and substantial variation in this regard within the sample.

Of course, this measure of trade policy is not ideal since aggregate shifts in import penetration could reflect various factors other than policy decisions (Leamer 1988; O'Rourke and Williamson 1999). However, the alternative measures that have been developed cover only a fraction of the countries included in our sample. Moreover, they exclude many autocracies and numerous developing countries, rendering them inappropriate for our purposes. ${ }^{3}$ It is especially important to include countries with as wide a range of political institutions and macroeconomic conditions as possible, given the arguments being tested in this paper. Recent studies of the impact of membership in the World Trade Organization (Rose 2004a, b; Subramanian and Wei 2003) or participation in multilateral bodies (Goldstein, Rivers, and Tomz 2003) including Free Trade Areas (Ingram, Robinson, and Busch 2003; Rose 2004c) have also used the aggregate

\footnotetext{
${ }^{3}$ For an overview of these measures, see Edwards (1993).
} 
value of trade as a measure of openness and have demonstrated that this procedure yields results that are much the same as those derived using a wide array of alternate measures. ${ }^{4}$ Furthermore, protectionist trade policies should generally reduce imports and trade liberalization should generally increase them. Consequently, while we consider the robustness of our results to an alternate measure of openness that is based on a gravity model of trade and discussed further below (Hiscox and Kastner 2002), there is ample reason to use $\triangle I M P O R T S_{i, t}$ in our core specification.

\section{$\underline{\text { Independent Variables }}$}

The central variables in our model are the unemployment rate (UNEMPL) and the extensiveness of veto points (POLCON) in each country. All of the independent variables are measured in year $t-1$, reflecting the fact that trade policy does not respond immediately to either societal pressures or institutional conditions and helping to address the possibility of endogeneity in the model.

As we mentioned earlier, societal theories frequently infer demands for protection from the unemployment rate. The World Bank reports the unemployment rate that is given by each country's national statistical agency. These data cover the widest possible range of countries and years, rendering them especially useful in light of this paper's objectives. ${ }^{5}$ Prior to 1980 , however, unemployment data for developing countries are not compiled using a comparable methodology, making cross-national comparisons very difficult to conduct. As such, our analysis centers on the period from 1980 to 2000 .

The key institutional factor included in the model is the extent of the constraints faced by government officials in each country. We measure this variable in terms of the veto points created by the structure of a country's political institutions and the extent of partisan heterogeneity within and across these institutions, using the Political Constraints Index $(P O L C O N)$ developed by Henisz (2000). ${ }^{6}$ The first step in constructing this time-varying index is the identification of the number of independent branches of government (executive, lower and

\footnotetext{
${ }^{4}$ As our interest is in the effect of societal and statist forces at the national level as opposed to the effect on dyadic trade of membership in a multilateral body by one or both parties, we use national import penetration as opposed to bilateral import flows as our dependent variable.

${ }^{5}$ Data from the International Labor Office offers equal coverage to the World Bank dataset and is drawn from the same national sources.

${ }^{6}$ Data and codebook are available from http://www-management.wharton.upenn.edu/henisz/POLCON/

ContactInfo.html
} 
upper legislative chambers, judiciary, and sub-federal institutions) with veto power over policy change in each country. Countries lacking any formal veto points are assigned a score of 0 . For all other countries, the majority preference of each of these branches and the status quo policy are then assumed to be independently and identically drawn from a uniform, unidimensional policy space [0,1]. This assumption allows for the derivation of a quantitative measure of institutional constraints using a simple spatial model of political interaction.

This initial measure is then modified to take into account the extent of alignment across branches of government using data on the party composition of the executive and legislative branches. Alignment across branches increases the feasibility of policy change, thereby reducing the level of political constraints. The measure is then further modified to capture the extent of preference heterogeneity within each legislative branch. Greater within-branch heterogeneity increases (decreases) the costs of overturning policy for aligned (opposed) branches. The final measure of POLCON can take on values ranging from zero (least constrained) to one (most constrained). This measure is available for all countries except microstates (data are missing for only 15 of the countries for which we have data on trade openness) in our sample. Since our argument is that the impact of societal forces on trade policy will be moderated as the number of veto points rises, we also analyze $U N E M P L * P O L C O N$.

Another key aspect of our argument is that the effects of broad societal pressures for protectionism as well as veto points should be qualitatively different in stable democratic nations than in other political regimes. We therefore generate two sets of parameter estimates, one for the democratic states in the sample and another for the non-democratic states. ${ }^{7}$ We distinguish between democratic and non-democratic regimes using the Polity IV dataset (Marshall and Jaggers 2001), which contains separate 11-point indices of each state's democratic (DEM) and autocratic (AUT) characteristics in each year. The difference between these indices (DEM$A U T=R E G$ ) yields an overall measure of regime type ranging from -10 to 10 (Jaggers and Gurr 1995). Following much of the existing literature, we define stable democratic regimes as those where $R E G$ is greater than or equal to 6 for five consecutive years. Later, however, we assess the robustness of the results by fluctuating this cut-off point for democracy.

\footnotetext{
${ }^{7}$ In our robustness tests, we further address this issue by pooling the democratic and non-democratic states in the sample and including a democracy indicator variable as described in further detail below.
} 
Since our dependent variable is the percentage change in import penetration, it is important to include the level of import penetration as well. There are practical limits on the extent of import penetration that countries can achieve. Those that are already relatively open may find it difficult to increase import penetration much, whereas those that are relatively closed will face strong economic incentives to liberalize their trade regimes. Controlling for initial conditions in this manner will help us to isolate the differing mechanisms that led to conflicting theoretical arguments and empirical evidence regarding the impact of veto players in extant research on trade liberalization (Frye and Mansfield 2003; Lohmann and O'Halloran 1994).

Although our primary interest is in the interaction between societal pressures and domestic institutions, it is obviously important to account for various additional factors that might influence foreign commerce too. To this end, we include: (1) the level and change in each country's real effective exchange rate (REER and $\triangle R E E R$ ), which alters the relative price of imports and thus demand for them; (2) the change in each state's terms of trade (TOT), which captures relative price movements particular to a country's imports or exports that may not be fully reflected in its exchange rate (e.g., the effect of an oil price shock on oil importers or oil exporters that control their exchange rate); (3) the government's supply of foreign exchange reserves as a percentage of imports (RES), which alters its ability to withstand a run on its currency and increases the likelihood that it will liberalize trade as part of a multilateral program to restore financial stability; (4) gross private capital formation $(G P C F)$, which plays a similar role to reserves in shaping trade policy; and (5) a vector of time-varying dummy variables indicating whether a country is a member of each of the fifty preferential trade agreements (PTA) that may require, encourage or solicit membership from those countries more likely to expand their overseas economic linkages (Ingram, Robinson, and Busch 2003). Further, we include dummy variables indicating whether each country was a member of the Organization of Petroleum Exporting Countries (OPEC) or the Council for Mutual Economic Cooperation (COMECON), since a heavy dependence on oil exports and a command economy are likely to influence the evolution of trade policy. Finally, to capture any unmeasured country-specific but time invariant or time-specific but country invariant heterogeneity in the data, we include country-specific and year-specific fixed effects. Note, however, that to conserve space we do not report the estimates of these dummy variables. 


\section{$\underline{\text { Results }}$}

We estimate the model described in the previous section using ordinary least squares (OLS). Tests of statistical significance are based on panel-corrected standard errors, which account for any heteroskedasticity, the fact that the data are grouped by country, and, through the estimation of a first order autoregressive error structure whose parameter $p$ is assumed constant across panels, by time (Beck and Katz 1995). Table 1 provides summary statistics and a correlation matrix for the variables included in our analysis.

The least-squares estimates are displayed in Table 2. In the first column, we enter only the indicator variables; in the second column, we enter these variables and the initial level of trade openness. The theoretical variables that are central to testing our argument are then included in the third column. In the fourth column, we add the remaining control variables described in the previous section. In the final two columns, we replicate the specification in column four, breaking the sample into stable democracies and other regime types, respectively. Because our argument is that the effects of societal influences are conditional on domestic political institutions, we focus our discussion of these influences on Figure 1, which presents the predicted marginal change in external trade linkages for a stable democracy with certain combinations of societal factors and institutional conditions, holding all other variables constant at their mean levels. The graph does not show the predicted change in trade policy for a specific or even a hypothetical county. Rather, it presents the predicted marginal change in import penetration resulting from varying unemployment rates and the level of political constraints as specified on the $\mathrm{x}$ - and $\mathrm{y}$-axes, compared to the predicted marginal change arising from all of the remaining independent variables in Table 2 (including the omitted country, PTA, and time indicator variables) multiplied by their respective coefficient estimates in model 5 (which contains the parameter estimates for democracies). In order to generate the total predicted change in trade policy, it is necessary to combine the partial effects displayed in Figure 1 with these additional variables for a specific country-year, a task that we do not undertake here.

The downward sloping schedules in Figure 1 show that, ceteris paribus, higher unemployment is associated with reductions in the import penetration and hence increased protectionism. Consistent with our argument, this effect is becomes stronger as the number of veto players declines. For example, in a stable democracy where the number of veto players is approximately one standard deviation below the mean for stable democracies (0.3) and the 
unemployment rate is 10 percent, the predicted change in external trade linkages is 10 percentage points lower than if the unemployment rate was 2 percent (a predicted reduction of 13 percentage points instead of 3 percentage points) and 7 percentage points lower than if the unemployment rate was a more realistic 5 percent (a predicted reduction of 13 percentage points instead of 6 percentage points). This relationship, however, is influenced by the number of veto players. For example, if political constraints are held at approximately their mean level for stable democracies (0.6), the impact of having an unemployment rate of 10 percent instead of 2 (5) percent falls from a decline of 10 (7) percentage points to a decline of 2.1 (1.3) percentage points.

As expected, the estimate for the initial level of import penetration is large and negative, indicating that relatively open countries are less likely to expand their external trade linkages than countries that are relatively closed. In addition, there is evidence that preferential trade agreements are positively associated with changes in import penetration (although we do not present these parameter estimates to conserve space). Increases in the terms of trade, the availability of local capital, and the stock of reserves are each associated with rising import penetration. So, too, is a higher real exchange rate, although changes in this rate have little effect on trade policy. Finally, the preferential trading agreement, year-specific, and country-specific indicator variables are jointly significant. Note that the use of these fixed effects is a less restrictive means of capturing the impact of a time trend, national size, coastline or distance from other countries which, if entered independently, would impose linear or other functional restrictions on each of the effects.

\section{$\underline{\text { Robustness Checks }}$}

Having generated some initial estimates of the model, it is important to assess the robustness of these results to alternate measures of the key constructs, alternate approaches to time series cross section error structures, and potentially omitted independent variables. To begin, we analyze a different measure of trade policy that was constructed by Hiscox and Kastner (2002). This measure involves using estimates of fixed country-year effects in a gravity model of trade flows to assess each state's trade policy in a given year. ${ }^{8}$ In Table 3, we replicate

\footnotetext{
${ }^{8}$ More specifically, they regressed the ratio of annual imports by country $i$ from country $j$ to $i$ 's annual GDP on $j$ 's annual GDP, $j$ 's annual per capita GDP, the geographical distance between $i$ and $j$, the yearly difference in $i$ 's and $j$ 's
} 
our initial results after replacing our original dependent variable with Hiscox and Kastner's measure. In interpreting these results, it is important to recognize that higher values of their measure indicate greater protectionism (the opposite interpretation of an increase in import penetration). As such, we expect the signs of the coefficient estimates in our model to be reversed when focusing on this variable, and the results in Table 3 bear out this expectation. Indeed, the effects of unemployment and political constraints in all countries and in stable democracies do not depend in any significant way on which measure of trade policy we analyze, even though there is a substantial reduction in the sample size when Hiscox and Kastner's measure is used, particularly among non-democracies. ${ }^{9}$

Next, it is useful to assess whether our results depend on how we have defined and measured stable democracies. Recall that we have coded a country as democratic if its regime type score based on the Polity index (which ranges from -10 to 10) is 6 or higher for five consecutive years. To begin, we redefine stable democracies as those country-years where this index exceeds 7 (as opposed to 6). These results, which are reported in Table 4 (models 1 and 2), are qualitatively similar to the base specifications in Table 2 (models 5 and 6). We also enter an indicator variable for stable democracies using both the original (6 and greater) and modified (7 and greater) thresholds into a pooled sample and once again find no substantive changes in the results of theoretical interest (see Table 4, models 3 and 4). These latter specifications suggest that democracy does not have a direct effect on changes in import penetration. Rather, the functional relationship between the structure of a nation's political institutions and societal pressures, on the hand, and changes in import penetration, on the other, differ between stable democracies and other countries.

We also examined an alternate measure of checks and balances: the Checks Index from the Database of Political Institutions $2000 .{ }^{10}$ Like the Political Constraint Index that we employ in our primary specification, CHECKS "counts the number of veto players in a political system, adjusting for whether these veto players are independent of each other, as determined by the level of electoral competitiveness in a system, their respective party affiliations, and the electoral

endowments of labor and capital, and fixed country-year effects. All of the continuous variables in the model are expressed in logarithmic form.

${ }^{9}$ Our results are also unchanged when we replace the percentage change in import penetration with the absolute change in import penetration or with the percentage or absolute change in overall trade openness, that is, the sum of a country's imports and exports divided by its gross domestic product.

${ }^{10}$ Available from http://www.worldbank.org/research/bios/pkeefer.htm. 
rules." The index yields a minimum score in the absence of an effective legislature. The index score then increases linearly with the addition of subsequent veto points whose political preferences are closer to the opposition ${ }^{11}$ than the average of the government using a three-point scale (Beck, Clarke, Groff, Keefer, \& Walsh, 2001).

While the CHECKS index takes into account the complex relationship between veto points, party preferences and preference heterogeneity, it also assumes a linear relationship between the number of adjusted veto points and the degree of constraints on policy change. Similarly, the number of adjusted veto points increases linearly in Parliamentary systems with each addition of a party to the ruling coalition without regard to the relative size of the parties in the coalition. Each of these results is at odds with much of the theoretical literature on veto points (Tsebelis 1995, 2003). As a result, we follow common practice and logarithmically transform the CHECKS index. The correlation between the transformed index and the Political Constraints Index is relatively high (0.67), but there are important cases where the two indexes diverge (see Henisz, 2004 for a description of these cases). The results displayed in Models 5-7 of Table 4 show that our results are robust to the use of this alternate measure of veto points.

Next, we address concerns of endogeneity by adopting the dynamic panel estimator of Arrelano and Bond (1991). Caselli et al. (1996) argue that OLS estimators such as we use in our primary specification are biased and inconsistent for two separate reasons. First, the countryspecific effects - including any omitted variables - are necessarily correlated with the other independent variables. Second, the control variables are likely, to some extent, to be endogenous. For example, decreasing openness may be a function of a short-term increase in unemployment. But if openness promotes growth (Wacziarg and Welch 2003), then in the long-term, openness should decrease unemployment. Ignoring this relationship will lead to upwardly biased coefficient estimates because the endogenous variable, in reality, appears on the right-hand side of the estimating equation. Furthermore, the estimators will be inconsistent since the regressors are correlated with the error term, which combines the error in the specified relationship with the error term in the simultaneous equation where unemployment is a function of openness.

A common practice in the literature is to use lagged variables as an instrument for potentially endogenous regressors in a three stage least squares regression. While this procedure addresses

\footnotetext{
${ }^{11}$ The opposition is defined as the largest opposition party in Presidential regimes and the three largest opposition parties in Parliamentary regimes.
} 
the endogeneity problem discussed above, it neglects the bias and inconsistency created by the omitted variable or fixed effect. Nor does it take into account any time specific shocks or time trends.

By contrast, Casseli et al. (1996) demonstrate that a generalized method of moments (GMM) estimator is consistent if three identifying assumptions are met: (1) there is no secondorder serial correlation, (2) "stock" variables in the model are predetermined at time $t$-2, and (3) "flow" variables are not predetermined at time $t-2$ but are predetermined at time $t-1$. To derive their GMM estimator, the authors use a two-step process suggested by Arellano and Bond (1991). A first-step estimate is made using the assumption of independently and identically distributed error terms. Consistent but inefficient (assuming heteroskedasticity) estimates of the error terms are computed and then used in a second stage regression in which the assumption of homoskedasticity imposed in the first stage is relaxed. The results using this Generalized Method of Moments estimator for stable democracies are largely unchanged, indicating that these results are quite robust. However, in the pooled sample or the subsample of other countries, there are some noticeable differences in the results (see Table 5). Nonetheless, consistent with our argument, we continue to find that the influence of unemployment on trade policy grows larger as the number of veto players declines in democracies, but that these factors have relatively bearing on commercial policy in non-democratic regimes

Finally, we examine a range of macroeconomic variables and country characteristics suggested by the literature as potential determinants of openness to ensure that they do not account for the observed effects of unemployment and veto points on trade policy. First, we use an alternate normalization for international reserves, a ratio of GDP instead of imports. Second, we analyze five different measures of inflation: (1) as derived from the consumer price index [CPI], (2) as derived from the GDP deflator, (3) the log of the CPI derived measure, (4) the $\log$ of the GDP deflator-derived measure, and (5) indicator variables for inflation levels in excess of 10 percent and 100 percent, respectively. High levels of inflation could signal an impending financial crisis, stimulating commercial reform (Krueger 1993; Rodrik 1996). Third, we analyze real gross domestic product. Economically large states may have the ability to impose an optimal tariff and have domestic alternatives to imports, thereby impeding trade liberalization. Fourth, we analyze real per capita GDP. Heightened economic development could enhance liberalization as a country increasingly trades in differentiated industrial products. Finally, we 
address four measures of inward capital flows -- gross foreign direct investment (FDI), gross FDI and portfolio investment, net FDI, net FDI and portfolio investment and the government budget balance -- which are additional measures of financial stability and thereby increase the likelihood of liberalization in the context of financial stabilization. Table 6 reports the results from these supplementary analyses for the subsample of stable democracies. The findings indicate that, with the exception of the alternate definition of gross international reserves, none of these variables are statistically significant; nor does their introduction into the primary specification substantively alter the empirical support for our hypotheses. Taken as a whole, then, the tests described in this section offer considerable evidence that our results are quite robust.

\section{$\underline{\text { Discussion }}$}

The results of this paper have various implications for research on the political economy of trade policy. First, social scientists have long debated the merits of societal and statist approaches. While many studies have privileged one approach over the other, our findings indicate the importance of acknowledging their interdependence. As many societal theories emphasize, changes in macroeconomic conditions influence the preferences of the populace at large. These preferences have a considerable bearing on foreign economic policy. At the same time, however, statist factors are also important in this regard. Both the number of veto points in a government and a country's regime type heavily influence its responsiveness to demands for change in its trade orientation.

Moreover, there is ample evidence that the interaction between societal and statist variables are central to shaping trade policy. Various studies have raised this issue, but remarkably little empirical research has directly confronted it (Gilligan 1997; Mansfield and Busch 1995; Milner 1997). The effects of unemployment depend heavily on the number of veto players that constrain decision makers and whether a country is democratic or not. High unemployment leads to protectionist trade policies in stable democracies marked by few veto players. As expected, however, the magnitude of this relationship becomes attenuated as the number of veto players rises, making it more difficult to change the existing trade regime and increasing the heterogeneity of the players' interests. Equally, macroeconomic fluctuations have a much more pronounced influence on the trade regime in democracies than other countries, 
reflecting the need for democratic leaders to be more responsive to demands made by the general population than their non-democratic counterparts.

Second, our results bear heavily on recent debates about the relationship between regime type and economic reform. Virtually all of the literature on this topic ignores the effects of institutional variations within both democracies and non-democracies alike. Such variations, however, are crucial to explaining changes in trade policy, especially in democracies. Holding macroeconomic conditions constant, the trade regime changes less within democracies as the number of veto players increases. Furthermore, as macroeconomic conditions worsen and societal calls for protectionism become louder and more widespread, increases in trade barriers are more likely to occur as the number of veto players declines. When a country's economy is thriving - marked by very low levels of unemployment - thereby creating a substantial constituency for expanding commercial openness, such an expansion is most likely to occur in countries with few veto points. Not only do these results indicate that regime type is just one aspect of the institutional influences on trade policy, they also point to the importance of veto points, a factor that has been underemphasized in existing studies of trade policy.

Similarly, we find that, within democracies, changes in import penetration are more likely to occur as the number of veto points declines. However, whether such changes lead to greater protection or liberalization hinges on the demands being issued by societal groups. When the economy is faltering, giving rise to calls for protection, a small number of veto points tends to promote greater closure; when the economy is flourishing, a small number of these points foster greater openness. Our results offer important qualifications to studies making unconditional comparisons between either domestic political concentration and fragmentation or democracy and autocracy on commercial openness and economic reform (Haggard 1990; Haggard and Kaufman 1995; Wade 1990). Just as the effects of societal forces depend on domestic institutions, the effects of institutions are contingent on societal forces.

Third, our focus in this paper has been on the domestic sources of overseas commerce. However, our results indicate that in addition to such sources, international organizations shape states' trade policy. For example, countries that are members of preferential trading agreements are more likely to expand their import penetration than states that do not participate in these organizations. This finding is hardly surprising, but in light of the emphasis that contemporary 
studies of foreign commerce place on domestic forces, it does serve as a useful reminder that such studies need to account for international forces as well (Goldstein, Rivers, and Tomz 2003).

\section{$\underline{\text { Conclusions }}$}

The remarkable expansion of global trade since World War II has stimulated a large and important literature, much of which stresses the effects of domestic politics on trade policy. This literature, however, has miscast certain aspects of the domestic determinants of trade policy. Whereas societal and statist factors are usually viewed as having independent and competing influences, these factors actually have an interactive effect on trade policy. Deteriorating macroeconomic conditions give rise to societal demands for protectionism. But the extent to which these demands are met and barriers to trade are put in place depends on the domestic political institutions through which societal pressures are filtered.

Furthermore, while a rising number of studies emphasize that democracy promotes open trade, the trade policy of democracies hinges on the extent of the constraints placed on leaders and the underlying societal pressures that these leaders face. When leaders face a greater number of veto points, it becomes harder to change policy. When unemployment soars, leaders face increased incentives to restrict commercial openness. Consequently, whether spreading democracy throughout the world will promote prosperity and free trade - as many observers have argued - depends on institutional factors within democracies, global and local macroeconomic conditions, and the patterns of domestic interest group competition. A better understanding of these factors and how they operate is crucial to improving our understanding of the political economy of trade policy. 
Table 1: Summary Statistics

\section{$\underline{\text { Variable }}$}

$\mathrm{N}$

Mean

Standard Deviation

Minimum

Maximum

Change in import penetration

Change in Hiscox/Kastner measure

Level of import penetration

Level of Hiscox Hiscox/Kastner measure

Political constraints

Checks

Unemployment Rate

Political constraints * Unemployment Rate

Real Effective Exchange Rate Index / 1000

Change in Real Effective Exchange Rate Index

Change in Terms of Trade / GDP

Gross Private Capital Formation / GDP

Gross International Reserves / Imports

Gross International Reserves / GDP

Inflation (CPI)

Inflation (GDP Deflator)

Log Inflation (CPI)

Log Inflation (GDP Deflator)

Inflation Indicator $(>33 \%<100 \%)$

Inflation Indicator $(>100 \%<1000 \%)$

Inflation Indicator $(>1000 \%)$

Real Gross Domestic Product (\$b)

Real Gross Domestic Product per capita (\$)

Gross Foreign Direct Investment / GDP

Net Foreign Direct Investment / GDP

Portfolio Investment / GDP

Government Budget Balance / GDP

Debt Service / GDP

Debt Service / Exports

Stable Democracy $(0,1)$
\#

$\begin{array}{llllllll}3093 & 1473 & 3124 & 1473 & 3398 & 3277 & 1172 & 1162\end{array}$

$\begin{array}{llllllll}0.02 & 0.02 & 37.54 & 31.72 & 0.28 & 0.62 & 8.17 & 4.53\end{array}$

$\begin{array}{llllllll}0.22 & 0.13 & 24.07 & 10.03 & 0.33 & 0.67 & 5.71 & 3.93\end{array}$

$\begin{array}{llllllll}-0.68 & -0.74 & 0.69 & 0.85 & 0.00 & 0.00 & 0.10 & 0.00\end{array}$

1

$2-0.25$

$\begin{array}{lll}3 & 0.24 & -0.15\end{array}$

$\begin{array}{lll}4 & -0.10 & 0.10\end{array}$

$5-0.10-0.12$

$\begin{array}{llllll}6 & -0.03 & -0.04 & 0.13 & -0.16 & 0.67\end{array}$

$\begin{array}{lllllll}7 & -0.08 & 0.17 & -0.14 & -0.13 & 0.04 & 0.11\end{array}$

$\begin{array}{llllllll}8 & -0.10 & -0.06 & 0.03 & -0.14 & 0.83 & 0.62 & 0.44\end{array}$

$\begin{array}{lllllllll}9 & -0.23 & 0.35 & -0.28 & 0.24 & -0.25 & -0.31 & -0.10 & -0.23\end{array}$

$\begin{array}{lllllllll}10 & -0.40 & -0.08 & 0.07 & -0.14 & 0.07 & 0.02 & 0.09 & 0.09\end{array}$

$\begin{array}{lllllllll}11 & -0.11 & -0.02 & -0.03 & -0.31 & -0.11 & -0.07 & -0.04 & -0.21\end{array}$

$\begin{array}{lllllllll}12 & -0.13 & 0.13 & 0.10 & -0.36 & 0.16 & 0.15 & 0.16 & 0.13\end{array}$

$\begin{array}{llllllllll}13 & -0.09 & 0.02 & -0.43 & 0.07 & 0.24 & 0.15 & 0.10 & 0.32\end{array}$

$\begin{array}{lllllllll}14 & -0.05 & -0.13 & 0.24 & -0.35 & 0.43 & 0.24 & 0.03 & 0.35\end{array}$

$\begin{array}{lllllllll}15 & 0.63 & -0.09 & 0.36 & -0.18 & -0.13 & -0.02 & 0.04 & -0.08\end{array}$

$\begin{array}{lllllllll}16 & 0.76 & -0.08 & 0.35 & -0.18 & -0.14 & -0.02 & 0.02 & -0.10\end{array}$

$\begin{array}{lllllllll}17 & 0.47 & -0.03 & 0.34 & -0.23 & -0.08 & 0.05 & 0.10 & -0.01\end{array}$

$\begin{array}{lllllllll}18 & 0.49 & -0.02 & 0.35 & -0.23 & -0.09 & 0.04 & 0.10 & -0.01\end{array}$

$\begin{array}{lllllllll}19 & -0.07 & 0.05 & -0.02 & -0.14 & 0.30 & 0.32 & 0.10 & 0.34\end{array}$

$\begin{array}{lllllllll}20 & -0.02 & -0.03 & -0.11 & -0.09 & 0.04 & 0.12 & 0.02 & 0.05\end{array}$

$\begin{array}{lllllllll}21 & 0.43 & -0.01 & 0.40 & -0.19 & -0.13 & -0.03 & 0.09 & -0.07\end{array}$

$\begin{array}{lllllllll}22 & -0.01 & -0.03 & -0.24 & 0.53 & -0.19 & -0.14 & -0.21 & -0.15\end{array}$

$\begin{array}{lllllllll}23 & -0.10 & -0.02 & 0.00 & -0.47 & 0.56 & 0.36 & 0.12 & 0.46\end{array}$

$\begin{array}{lllllllll}24 & -0.06 & -0.17 & 0.45 & -0.31 & 0.34 & 0.23 & -0.10 & 0.15\end{array}$

$\begin{array}{lllllllll}25 & -0.06 & -0.13 & 0.50 & -0.29 & 0.37 & 0.26 & -0.09 & 0.17\end{array}$

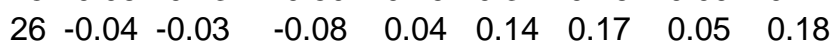

$\begin{array}{lllllllll}27 & -0.31 & 0.08 & -0.16 & -0.13 & 0.17 & 0.08 & 0.14 & 0.20\end{array}$

$\begin{array}{lllllllll}28 & -0.10 & 0.11 & 0.27 & -0.33 & 0.21 & 0.00 & 0.28 & 0.21\end{array}$

$\begin{array}{lllllllll}29 & -0.09 & 0.24 & -0.17 & -0.09 & -0.03 & -0.09 & 0.36 & 0.07\end{array}$

$\begin{array}{lllllllll}30 & -0.06 & 0.02 & -0.24 & -0.03 & 0.63 & 0.46 & 0.20 & 0.66\end{array}$
0.03

$0.06-0.12$

$\begin{array}{lll}-0.10 & 0.08 & 0.10\end{array}$

$0.03-0.06-0.03$

$\begin{array}{lll}-0.16 & 0.07 & -0.01 \\ -0.33 & 0.17 & -0.26\end{array}$

$\begin{array}{lll}-0.33 & 0.17 & -0.26\end{array}$

$\begin{array}{llll}-0.31 & -0.02 & -0.22\end{array}$

$\begin{array}{llll}-0.41 & 0.27 & -0.28\end{array}$

$\begin{array}{lll}-0.41 & 0.22 & -0.27\end{array}$

$\begin{array}{lll}-0.33 & -0.09 & -0.10\end{array}$

$\begin{array}{lll}-0.16 & 0.03 & 0.13\end{array}$

$\begin{array}{lll}-0.31 & 0.29 & -0.30\end{array}$

$\begin{array}{llll}0.05 & -0.07 & -0.06\end{array}$

$\begin{array}{llll}-0.20 & -0.03 & 0.23\end{array}$

$\begin{array}{lll}-0.18 & -0.04 & 0.23\end{array}$

$\begin{array}{lll}-0.14 & -0.01 & 0.23\end{array}$

$\begin{array}{llll}-0.09 & -0.02 & -0.14\end{array}$

$\begin{array}{lll}-0.01 & -0.28 & 0.25\end{array}$

$\begin{array}{lll}-0.08 & 0.16 & 0.05\end{array}$

$\begin{array}{llll}0.10 & 0.16 & -0.01\end{array}$

$\begin{array}{lll}-0.09 & -0.03 & -0.21\end{array}$
0.22

$\begin{array}{lll}0.38 & 0.72 & 0.39\end{array}$

$\begin{array}{lll}-0.06 & -0.16 & -0.05\end{array}$

$\begin{array}{lll}-0.06 & -0.16 & -0.05\end{array}$

$\begin{array}{llll}0.03 & -0.12 & -0.04\end{array}$

$\begin{array}{lll}0.03 & -0.12 & -0.06\end{array}$

$\begin{array}{lll}0.26 & 0.12 & 0.10\end{array}$

$\begin{array}{lll}0.06 & 0.09 & -0.04\end{array}$

$\begin{array}{llll}-0.02 & -0.18 & -0.06\end{array}$

$\begin{array}{lll}-0.10 & 0.20 & 0.09\end{array}$

$\begin{array}{lll}0.43 & 0.58 & 0.39\end{array}$

$\begin{array}{llll}0.27 & -0.04 & -0.12\end{array}$

$\begin{array}{llll}0.19 & -0.08 & -0.14\end{array}$

$\begin{array}{lll}0.60 & 0.27 & 0.28\end{array}$

$\begin{array}{lll}0.18 & 0.30 & 0.10\end{array}$

$\begin{array}{lll}0.38 & -0.11 & -0.03\end{array}$

$\begin{array}{lll}0.23 & -0.02 & -0.02\end{array}$

$\begin{array}{lll}0.03 & 0.23 & 0.40\end{array}$ 
Table 1: Summary Statistics (continued)

$\underline{\text { Variable }}$

Mean

Standard Deviation

Minimum

Maximum

Change in import penetration

Change in Hiscox indicator

Level of import penetration

Level of Hiscox indicator

Political constraints

Checks

Unemployment Rate

Political constraints X Unemployment Rate

Real Effective Exchange Rate Index / 1000

Change in Real Effective Exchange Rate Index

Change in Terms of Trade / GDP

Gross Private Capital Formation / GDP

Gross International Reserves / Imports

Gross International Reserves / GDP

Inflation (CPI)

Inflation (GDP Deflator)

Log Inflation (CPI)

Log Inflation (GDP Deflator)

Inflation Indicator $(>33 \%<100 \%)$

Inflation Indicator $(>100 \%<1000 \%)$

Inflation Indicator $(>1000 \%)$

Real Gross Domestic Product (\$b)

Real Gross Domestic Product per capita (\$)

Gross Foreign Direct Investment / GDP

Net Foreign Direct Investment / GDP

Portfolio Investment / GDP

Government Budget Balance / GDP

Debt Service / GDP

Debt Service / Exports

Stable Democracy? $\begin{array}{lllllllllllllllll}69.17 & 79.83 & 4.81 & 4.82 & 0.09 & 0.04 & 0.01 & 177.00 & 5973.67 & 2.42 & 1.48 & 0.00 & -3.84 & 5.66 & 19.14 & 0.34\end{array}$

$\begin{array}{llllllllllllllll}636.33 & 743.69 & 0.43 & 0.47 & 0.28 & 0.19 & 0.11 & 700.00 & 9340.94 & 3.92 & 2.92 & 0.03 & 6.23 & 5.51 & 14.81 & 0.47\end{array}$

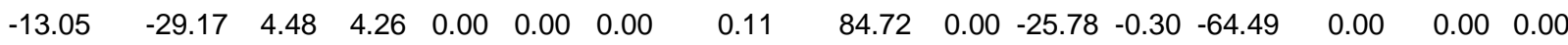

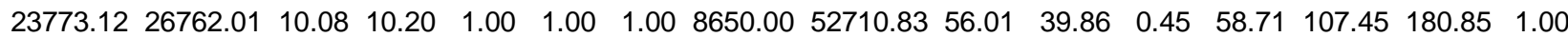

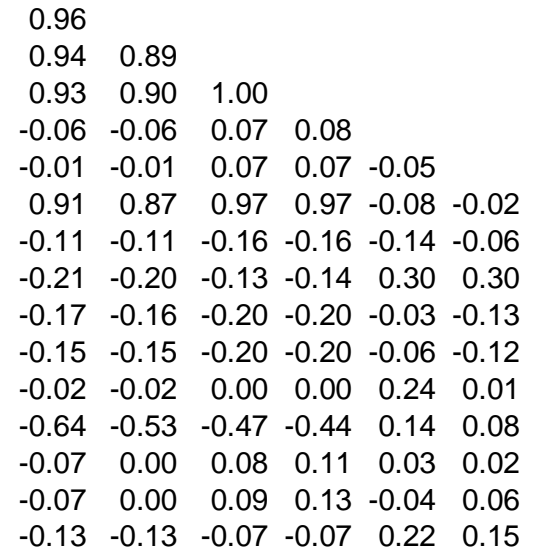

$-0.12$

$-0.24$

$-0.18$

$-0.17$

$-0.03$

$-0.47$

0.14

0.14

$-0.15$
$-0.19$

$0.14 \quad 0.24$

$\begin{array}{lll}0.11 & 0.22 & 0.92\end{array}$

$\begin{array}{llll}0.02 & 0.16 & -0.01 & -0.04\end{array}$

$\begin{array}{lllll}0.02 & 0.35 & 0.22 & 0.17 & 0.04\end{array}$

$\begin{array}{llllll}-0.20 & 0.19 & 0.12 & 0.10 & 0.05 & 0.27\end{array}$

$\begin{array}{lllllll}-0.16 & 0.05 & -0.16 & -0.18 & -0.03 & 0.26 & 0.80\end{array}$

$\begin{array}{llllllll}-0.10 & 0.34 & 0.06 & 0.05 & 0.08 & 0.23 & -0.01 & 0.08\end{array}$ 
Table 2: Effects of Unemployment and Political Constraints on Trade Policy, 1980-2000

(1)

N

\# Countries

R-squared

Sample

Level of Import Penetration

Political Constraints

Unemployment Rate

Political Constraints *

Unemployment Rate

Real Effective Exchange

Rate

Change in Real Effective

Exchange Rate

Change in Terms of Trade

Gross Private Capital

Formation / GDP

Gross International

Reserves / Imports

All
(2)

2532
149
0.18

2532

149

0.30

All

(3)

(4)

$1008 \quad 731$

$96 \quad 58$

$0.30 \quad 0.72$

All

All

$-0.012$

0.000

$\begin{array}{cc}-0.012 & -0.007 \\ 0.000 & 0.000 \\ 0.001 & -0.136 \\ 0.987 & 0.014 \\ -0.001 & -0.005 \\ 0.858 & 0.087 \\ 0.001 & 0.012 \\ 0.877 & 0.007 \\ & 0.000 \\ & 0.000 \\ & -0.031 \\ & 0.450 \\ & 0.721 \\ & 0.001 \\ & 0.001 \\ & 0.013 \\ & 0.014 \\ & 0.000\end{array}$

(5)

(6)

$587 \quad 144$

$44 \quad 26$

$0.39 \quad 0.90$

$\begin{array}{rr}\text { stable } & \begin{array}{r}\text { other } \\ \text { democracies }\end{array} \\ & \\ \text { countries } \\ -0.009 & -0.013 \\ 0.000 & 0.000 \\ -0.273 & -0.055 \\ 0.000 & 0.628 \\ -0.023 & -0.001 \\ 0.001 & 0.749 \\ 0.034 & -0.013 \\ 0.000 & 0.235 \\ -0.001 & 0.000 \\ 0.164 & 0.000 \\ -0.102 & 0.027 \\ 0.117 & 0.586 \\ 0.626 & 1.247 \\ 0.007 & 0.004 \\ 0.001 & -0.002 \\ 0.026 & 0.479 \\ 0.012 & 0.026 \\ 0.001 & 0.003\end{array}$

Notes: P-values reported in italics under OLS coefficient estimates using panel-corrected standard errors. Coefficient estimates on IGO, country and year indicator variables are not reported to conserve space. 
Table 3: Effects of Unemployment and Political Constraints on the Hiscox/Kastner Measure of Trade Policy, 1980-2000

\begin{tabular}{|c|c|c|c|c|c|c|}
\hline & (1) & (2) & (3) & (4) & (5) & (6) \\
\hline $\mathrm{N}$ & 1063 & 1063 & 480 & 375 & 299 & 76 \\
\hline \# Countries & 82 & 82 & 51 & 38 & 30 & 11 \\
\hline R-squared & 0.23 & 0.26 & 0.33 & 0.37 & 0.37 & 0.78 \\
\hline Sample & All & All & All & All & $\begin{array}{r}\text { stable } \\
\text { democracies }\end{array}$ & $\begin{array}{r}\text { other } \\
\text { countries }\end{array}$ \\
\hline Hiscox/Kastner Measure & & -0.014 & -0.018 & -0.023 & -0.027 & -0.018 \\
\hline Political Constraints & & 0.000 & $\begin{array}{l}0.000 \\
0.166 \\
0.029\end{array}$ & $\begin{array}{l}0.000 \\
0.186 \\
0.099\end{array}$ & $\begin{array}{c}0.000 \\
0.769 \\
0.025\end{array}$ & $\begin{array}{c}0.000 \\
0.165 \\
0.028\end{array}$ \\
\hline Unemployment Rate & & & $\begin{array}{l}0.006 \\
0.085\end{array}$ & $\begin{array}{l}0.008 \\
0.010\end{array}$ & $\begin{array}{l}0.033 \\
0.106\end{array}$ & $\begin{array}{l}0.005 \\
0.014\end{array}$ \\
\hline $\begin{array}{l}\text { Political Constraints * } \\
\text { Unemployment Rate }\end{array}$ & & & $\begin{array}{l}-0.034 \\
0.004\end{array}$ & $\begin{array}{c}-0.038 \\
0.005\end{array}$ & $\begin{array}{c}-0.076 \\
0.016\end{array}$ & $\begin{array}{r}-0.028 \\
0.015\end{array}$ \\
\hline Real Effective Exchange & & & & 0.000 & 0.001 & 0.000 \\
\hline Rate & & & & 0.671 & 0.155 & 0.542 \\
\hline Change in Real Effective & & & & -0.021 & -0.164 & 0.005 \\
\hline Exchange Rate & & & & 0.349 & 0.086 & 0.728 \\
\hline Change in Terms of Trade & & & & -0.013 & -0.077 & $\begin{array}{l}-0.357 \\
0.259\end{array}$ \\
\hline Gross Private Capital & & & & 0.000 & 0.000 & -0.001 \\
\hline Formation / GDP & & & & 0.878 & 0.876 & 0.727 \\
\hline Gross International & & & & -0.001 & 0.003 & -0.191 \\
\hline Reserves / Imports & & & & 0.725 & 0.592 & 0.234 \\
\hline
\end{tabular}

Notes: P-values reported in italics under OLS coefficient estimates using panel-corrected standard errors. Coefficient estimates on IGO, country and year indicator variables are not reported to conserve space. The value of the Hiscox/Kastner measure is inversely correlated with the degree of trade openness. 
Table 4: Effects of Unemployment and Political Constraints on Trade Policy, 1980-2000 Using Alternate Measures of Political Institutions

\begin{tabular}{|c|c|c|c|c|c|c|c|}
\hline & (1) & (2) & (3) & (4) & (5) & (6) & (7) \\
\hline $\mathrm{N}$ & 570 & 161 & 731 & 731 & 723 & 583 & 140 \\
\hline \# Countries & 40 & 28 & 58 & 58 & 58 & 45 & 25 \\
\hline R-squared & 0.37 & 0.88 & 0.72 & 0.72 & 0.72 & 0.38 & 0.90 \\
\hline Sample & $\begin{array}{r}\text { stable } \\
\text { democracies }\end{array}$ & $\begin{array}{r}\text { other } \\
\text { countries }\end{array}$ & All & All & & $\begin{array}{r}\text { stable } \\
\text { democracies }\end{array}$ & $\begin{array}{r}\text { other } \\
\text { countries }\end{array}$ \\
\hline \multirow[t]{2}{*}{ Level of Import Penetration } & -0.010 & -0.010 & -0.007 & -0.007 & -0.007 & -0.010 & -0.012 \\
\hline & 0.000 & 0.000 & 0.000 & 0.000 & 0.000 & 0.000 & 0.000 \\
\hline \multirow{2}{*}{$\begin{array}{l}\text { Measure of Political } \\
\text { Institutions (See Note) }\end{array}$} & -0.320 & -0.151 & -0.143 & -0.138 & -0.048 & -0.061 & -0.015 \\
\hline & 0.000 & 0.173 & 0.011 & 0.014 & 0.047 & 0.060 & 0.751 \\
\hline \multirow[t]{2}{*}{ Unemployment Rate } & -0.033 & -0.001 & -0.005 & -0.005 & -0.005 & -0.010 & 0.005 \\
\hline & 0.001 & 0.797 & 0.082 & 0.087 & 0.160 & 0.086 & 0.433 \\
\hline Political Constraints * & 0.045 & 0.005 & 0.012 & 0.012 & 0.006 & 0.009 & -0.008 \\
\hline Unemployment Rate & 0.001 & 0.629 & 0.007 & 0.007 & 0.029 & 0.019 & 0.231 \\
\hline Real Effective Exchange & -0.001 & 0.000 & 0.000 & 0.000 & 0.000 & -0.001 & 0.000 \\
\hline Rate & 0.218 & 0.000 & 0.000 & 0.000 & 0.000 & 0.067 & 0.000 \\
\hline Change in Real Effective & -0.119 & -0.005 & -0.029 & -0.031 & -0.034 & -0.104 & 0.018 \\
\hline Exchange Rate & 0.079 & 0.919 & 0.468 & 0.452 & 0.416 & 0.118 & 0.731 \\
\hline \multirow[t]{2}{*}{ Change in Terms of Trade } & 0.620 & 0.933 & 0.702 & 0.715 & 0.662 & 0.636 & 1.500 \\
\hline & 0.009 & 0.025 & 0.001 & 0.001 & 0.002 & 0.007 & 0.010 \\
\hline Gross Private Capital & 0.001 & 0.003 & 0.001 & 0.001 & 0.001 & 0.001 & -0.002 \\
\hline Formation / GDP & 0.034 & 0.287 & 0.015 & 0.013 & 0.009 & 0.012 & 0.412 \\
\hline Gross International & 0.012 & 0.027 & 0.013 & 0.014 & 0.012 & 0.010 & 0.027 \\
\hline Reserves / Imports & 0.001 & 0.002 & 0.000 & 0.000 & 0.000 & 0.003 & 0.002 \\
\hline \multirow[t]{2}{*}{ Stable Democracy $(0,1)$} & & & 0.033 & 0.010 & & & \\
\hline & & & 0.123 & 0.659 & & & \\
\hline
\end{tabular}

Note: P-values reported in italics under OLS coefficient estimates using panel-corrected standard errors.

Coefficient estimates on IGO, country and year indicator variables are not reported to conserve space.

Models (1)-(3) define stable democracies using a threshold of 6 on the Polity scale;

Models (3)-(4) include an indicator variable for stable democracies into the full sample; and

Models (5)-(7) use the CHECKS index instead of the Political Constraint Index. 
Table 5: Effects of Unemployment and Political Constraints on Trade Policy, 1980-2000 Using the Generalized Method of Moments Estimator of Arellano and Bond (1991)

\begin{tabular}{|c|c|c|c|c|c|}
\hline & (1) & (2) & (3) & (4) & (5) \\
\hline $\mathrm{N}$ & 2353 & 947 & 661 & 550 & 111 \\
\hline \# Countries & 148 & 82 & 53 & 42 & 21 \\
\hline Log-Likelihood & 624.34 & 3546.70 & 4437.01 & 6353.74 & 6307.80 \\
\hline Sample & All & All & All & $\begin{array}{r}\text { stable } \\
\text { democracies }\end{array}$ & $\begin{array}{r}\text { other } \\
\text { countries }\end{array}$ \\
\hline \multirow[t]{2}{*}{ Level of Import Penetration } & -0.021 & -0.019 & -0.007 & -0.009 & -0.015 \\
\hline & 0.000 & 0.000 & 0.001 & 0.000 & 0.015 \\
\hline \multirow{2}{*}{ Political Constraints } & & 0.132 & -0.189 & -0.331 & -0.021 \\
\hline & & 0.211 & 0.082 & 0.000 & 0.912 \\
\hline \multirow[t]{2}{*}{ Unemployment Rate } & & 0.001 & -0.005 & -0.034 & 0.001 \\
\hline & & 0.767 & 0.318 & 0.000 & 0.875 \\
\hline Political Constraints * & & -0.012 & 0.012 & 0.048 & -0.033 \\
\hline Unemployment Rate & & 0.194 & 0.093 & 0.000 & 0.078 \\
\hline Real Effective Exchange & & & 0.000 & -0.001 & 0.000 \\
\hline Rate & & & 0.000 & 0.244 & 0.000 \\
\hline Change in Real Effective & & & -0.025 & -0.153 & 0.056 \\
\hline Exchange Rate & & & 0.765 & 0.011 & 0.490 \\
\hline \multirow[t]{2}{*}{ Change in Terms of Trade } & & & 0.798 & 0.648 & 1.047 \\
\hline & & & 0.004 & 0.000 & 0.031 \\
\hline Gross Private Capital & & & 0.001 & 0.001 & 0.005 \\
\hline Formation / GDP & & & 0.141 & 0.125 & 0.806 \\
\hline Gross International & & & 0.013 & 0.012 & 0.026 \\
\hline Reserves / Imports & & & 0.008 & 0.008 & 0.031 \\
\hline HO: No 2nd order autcorrelation & $p=0.124$ & $p=0.754$ & $p=0.607$ & $p=0.153$ & $p=0.456$ \\
\hline
\end{tabular}

Note: P-values reported in italics under OLS coefficient estimates using dynamic panel estimator.

Coefficient estimates on IGO, country and year indicator variables are not reported to conserve space. 
Table 6: Effects of Unemployment and Political Constraints on Trade Policy, 1980-2000 Rotating in Potentially Omitted Variables

\begin{tabular}{|c|c|c|c|c|c|c|c|c|c|c|c|c|c|}
\hline & (1) & (2) & (3) & (4) & (5) & (6) & (7) & (8) & (9) & (10) & (11) & (12) & (13) \\
\hline N & 587 & 585 & 587 & 585 & 587 & 587 & 587 & 587 & 581 & 557 & 581 & 557 & 538 \\
\hline \# Countries & 44 & 44 & 44 & 44 & 44 & 44 & 44 & 44 & 44 & 43 & 44 & 43 & 41 \\
\hline R-squared & 0.37 & 0.39 & 0.39 & 0.39 & 0.39 & 0.39 & 0.39 & 0.39 & 0.39 & 0.39 & 0.39 & 0.39 & 0.39 \\
\hline \multirow[t]{2}{*}{ Level of Import Penetration } & -0.010 & -0.009 & -0.009 & -0.009 & -0.009 & -0.010 & -0.010 & -0.010 & -0.010 & -0.011 & -0.010 & -0.011 & -0.009 \\
\hline & 0.000 & 0.000 & 0.000 & 0.000 & 0.000 & 0.000 & 0.000 & 0.000 & 0.000 & 0.000 & 0.000 & 0.000 & 0.000 \\
\hline \multirow[t]{2}{*}{ Political Constraints } & -0.258 & -0.274 & -0.261 & -0.274 & -0.254 & -0.265 & -0.246 & -0.249 & -0.245 & -0.304 & -0.244 & -0.306 & -0.251 \\
\hline & 0.000 & 0.001 & 0.001 & 0.000 & 0.001 & 0.000 & 0.001 & 0.001 & 0.001 & 0.000 & 0.001 & 0.000 & 0.001 \\
\hline \multirow[t]{2}{*}{ Unemployment Rate } & -0.022 & -0.022 & -0.021 & -0.022 & -0.021 & -0.022 & -0.022 & -0.022 & -0.021 & -0.027 & -0.021 & -0.027 & -0.024 \\
\hline & 0.001 & 0.002 & 0.005 & 0.002 & 0.004 & 0.002 & 0.002 & 0.001 & 0.002 & 0.000 & 0.002 & 0.000 & 0.001 \\
\hline \multirow{4}{*}{$\begin{array}{l}\text { Political Constraints * } \\
\text { Unemployment Rate } \\
\text { Real Effective Exchange } \\
\text { Rate }\end{array}$} & 0.033 & 0.033 & 0.033 & 0.034 & 0.032 & 0.034 & 0.032 & 0.031 & 0.032 & 0.040 & 0.032 & 0.040 & 0.037 \\
\hline & 0.000 & 0.001 & 0.002 & 0.001 & 0.001 & 0.001 & 0.001 & 0.002 & 0.001 & 0.000 & 0.001 & 0.000 & 0.000 \\
\hline & -0.001 & -0.001 & -0.001 & -0.001 & -0.001 & -0.001 & -0.001 & -0.001 & -0.001 & -0.001 & -0.001 & -0.001 & -0.001 \\
\hline & 0.161 & 0.169 & 0.187 & 0.170 & 0.231 & 0.237 & 0.105 & 0.179 & 0.099 & 0.184 & 0.101 & 0.176 & 0.072 \\
\hline \multirow{2}{*}{$\begin{array}{l}\text { Change in Real Effective } \\
\text { Exchange Rate }\end{array}$} & -0.103 & -0.099 & -0.106 & -0.099 & -0.108 & -0.099 & -0.088 & -0.096 & -0.091 & -0.119 & -0.092 & -0.117 & -0.088 \\
\hline & 0.124 & 0.134 & 0.109 & 0.134 & 0.103 & 0.130 & 0.190 & 0.190 & 0.179 & 0.070 & 0.176 & 0.070 & 0.186 \\
\hline \multirow[t]{2}{*}{ Change in Terms of Trade } & 0.653 & 0.624 & 0.624 & 0.624 & 0.622 & 0.629 & 0.684 & 0.649 & 0.697 & 0.755 & 0.712 & 0.733 & 0.700 \\
\hline & 0.006 & 0.008 & 0.008 & 0.008 & 0.008 & 0.007 & 0.005 & 0.010 & 0.005 & 0.003 & 0.005 & 0.005 & 0.005 \\
\hline \multirow{2}{*}{$\begin{array}{l}\text { Gross Private Capital } \\
\text { Formation / GDP }\end{array}$} & 0.001 & 0.001 & 0.001 & 0.001 & 0.001 & 0.001 & 0.001 & 0.001 & 0.001 & 0.001 & 0.001 & 0.001 & 0.001 \\
\hline & 0.030 & 0.023 & 0.027 & 0.023 & 0.029 & 0.034 & 0.043 & 0.025 & 0.099 & 0.007 & 0.106 & 0.004 & 0.090 \\
\hline \multirow{2}{*}{\multicolumn{2}{|c|}{$\begin{array}{l}\text { Gross International } \\
\text { Reserves / Imports }\end{array}$}} & 0.012 & 0.012 & 0.012 & 0.012 & 0.012 & 0.012 & 0.012 & 0.012 & 0.012 & 0.012 & 0.012 & 0.012 \\
\hline & & 0.001 & 0.001 & 0.001 & 0.001 & 0.001 & 0.001 & 0.001 & 0.001 & 0.001 & 0.002 & 0.001 & 0.001 \\
\hline \multirow{4}{*}{$\begin{array}{l}\text { Rotated Variable(s) } \\
\text { (See Note) }\end{array}$} & 0.200 & 0.000 & 0.000 & 0.002 & 0.025 & 0.029 & 0.000 & 0.000 & 0.000 & 0.000 & 0.001 & -0.003 & 0.000 \\
\hline & 0.022 & 0.967 & 0.739 & 0.960 & 0.461 & 0.282 & 0.384 & 0.157 & 0.966 & 0.407 & 0.768 & 0.444 & 0.685 \\
\hline & & & & & & 0.038 & & & & 0.090 & & 0.080 & \\
\hline & & & & & & 0.331 & & & & 0.623 & & 0.669 & \\
\hline
\end{tabular}

Note: P-values reported in italics under OLS coefficient estimates using dynamic panel estimator.

Coefficient estimates on IGO, country and year indicator variables are not reported to conserve space.

We rotate in the following variable(s) in the noted model number (1) Gross International Reserves / GDP (2) Inflation, CPI;

(3) Inflation, GDP; (4) Log Inflation, CPI; (5) Log Inflation, GDP; (6) Inflation Indicator Variables; (7) Real GDP;

(8) Real Per Capita GDP; (9) gross FDI inflows; (10) gross FDI inflows and portfolio inflows; (11) net FDI inflows;

(12) net FDI inflows and portfolio flows; and (13) government budget balance. 
Figure 1: Political Constraints Moderate Societal Pressures for Protectionism

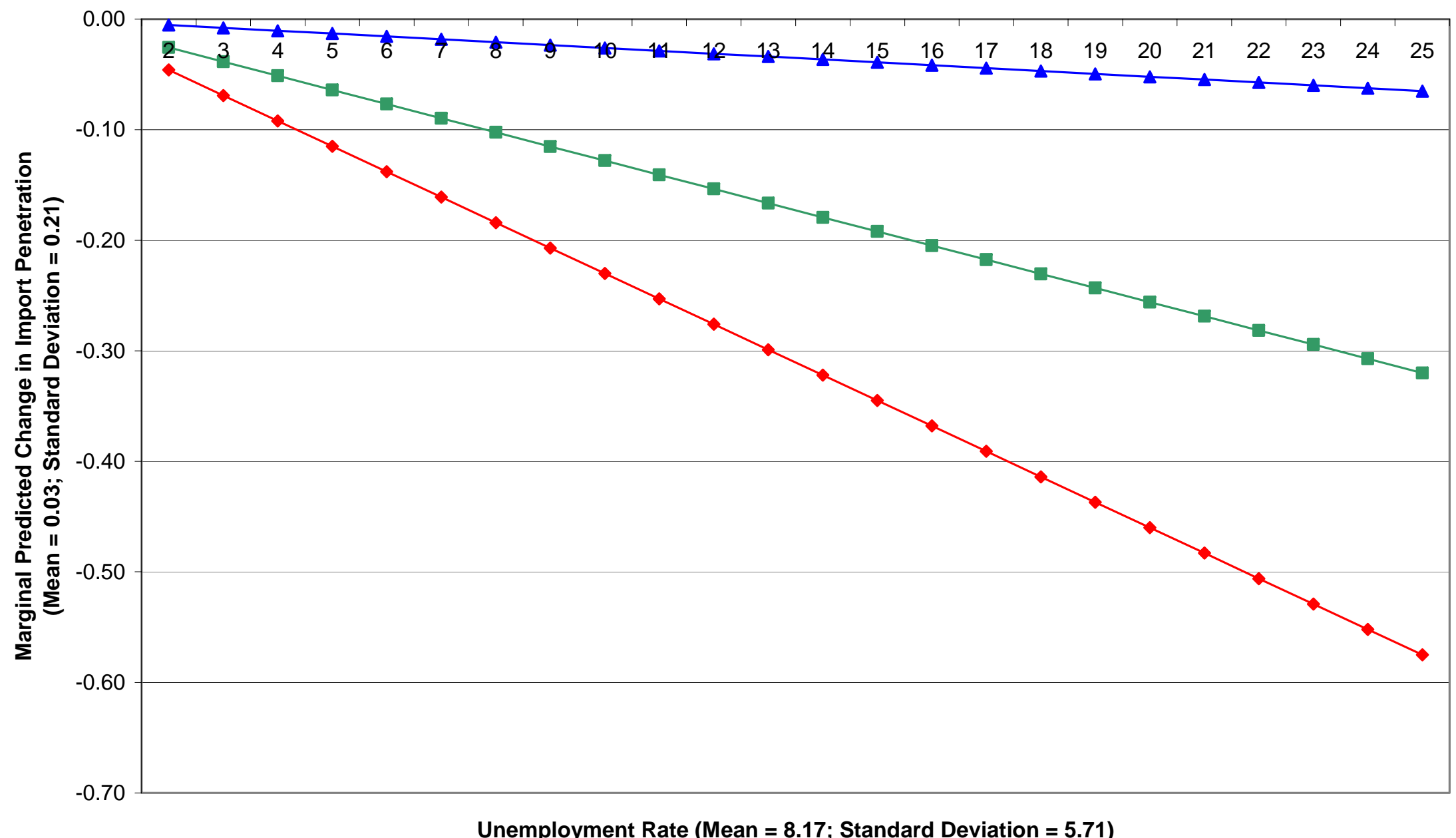

Low POLCON - - -Mean POLCON $₫$ High POLCON 


\section{$\underline{\text { References }}$}

Acemoglu, Daron, and James Robinson. The Political Origins of Dictatorship and Democracy 2003 [cited. Available from http://econwww.mit.edu/faculty/?prof id=acemoglu\&type=books.

Arellano, Manuel, and Stephen Bond. 1991. Some Tests of Specification for Panel Data: Monte Carlo Evidence and an Application to Employment Equations. Review of Economic Studies 58 (2):277-298.

Baldwin, Robert. 1989. U.S. Trade Policy: Recent Changes and Future U.S. Interests. American Economic Review 79 (2):128-133.

Beck, Nathaniel, and Jonathan N. Katz. 1995. What to Do (and Not to Do) with TimeSeries-Cross-Section Data in Comparative Politics. American Political Science Review 89 (3):634-47.

Beck, Thorsten, George Clarke, Alberto Groff, Philip Keeler, and Patrick Walsh. 2001. New Tools and New Tests in Comparative Political Economy: The Database of Political Institutions. World Bank Economic Review 15 (1):165-176.

Bergsten, Fred, and William R. Cline. 1983. Trade Policy in the 1980s: An Overview. In Trade Policy in the 1980s, edited by William R. Cline. Washington, DC: Institute for International Economics.

Bhagwati, Jagdish. 1991. The World Trading System at Risk. Princeton, NJ: Princeton University Press.

Bliss, Harry, and Bruce Russett. 1998. Democratic Trading Partners: The Liberal Connection, 1962-1989. Journal of Politics 60 (4):1126-1147.

Bohara, Alok K., and William H. Kaempfer. 1991. A Test of Tariff Endogeneity in the United States. American Economic Review 81 (4):952-960.

Bradford, Scott. Protection and Unemployment June 2003 [cited. Available from http://www.nottingham.ac.uk/economics/leverhulme/conferences/june 2003/Bradford.pd f.

Brooker, Paul. 2000. Non-Democratic Regimes: Theory, Government and Politics. New York: Palgrave Macmillan.

Caselli, Francesco, Gerardo Esquivel, and Fernando Lefort. 1996. Reopening the Convergence Debate: A new look at cross-country growth empirics. Journal of Economic Growth 1 (3):363-390.

Cline, William R. 1989. Macroeconomic Influences on Trade Policy. American Economic Review 79 (2):123-127.

Colton, Timothy. 2000. Transitional Citizens: Voters and What Influences Them in the New Russia. Cambridge, Mass.: Harvard University Press.

Corden, W. Max. 1993. The Revival of Protectionism in Developed Countries. In Protectionism and World Welfare, edited by Dominick Salvatore. New York: Cambridge University Press.

Deardorff, Alan V., and Robert M. Stern. 1987. Current Issues in Trade Policy: An Overview. In U.S. Trade Policies in a Changing World Economy, edited by Robert M. Stern. Cambridge, Mass.: MIT Press.

Destler, I. M. 1992. American Trade Politics. 2nd ed. Washington, DC: Institute for International Economics. 
Dornbusch, Rudiger, and Jeffrey A. Frankel. 1987. Macroeconomics and Protection. In U.S. Trade Policies in a Changing World Economy, edited by Robert M. Stern. Cambridge, Mass.: MIT Press.

Edwards, Sebastian. 1993. Openness, Trade Liberalization, and Growth in Developing Countries. Journal of Economic Literature 31 (3):1358-1393.

Franzese Jr., Robert J. 1999. The Positive Political Economy of Public Debt: An Empirical Examination of the OECD Postwar Debt Experience. Department of Political Science, University of Michigan.

Frye, Timothy, and Edward Mansfield. 2003. Fragmenting Protection: The Political Economy of Trade Policy in the Post-Communist World. British Journal of Political Science 33 (4):633-657.

Gardner, Grant W., and Kent P. Kimbrough. 1989. The Behavior of U.S. Tariff Rates. American Economic Review 79 (1):211-218.

Gilligan, Michael J. 1997. Lobbying as a Private Good with Intra-Industry Trade. International Studies Quarterly 41 (3):455-474.

Goldstein, Judith, Douglas Rivers, and Michael Tomz. 2003. How Does the Trade Regime Affect International Trade? Paper presented at the annual meeting of the American Political Science Association, Philadelphia, PA.

Haggard, Stephan. 1990. Pathways from the Periphery: The Politics of Growth in the Newly Industrializing Countries. Ithaca, NY: Cornell University Press.

Haggard, Stephen, and Robert Kaufman. 1995. The Political Economy of Democratic Transitions. Princeton, NJ: Princeton University Press.

Hallerberg, Mark, and Scott Basinger. 1998. Internationalization and Changes in Tax Policy in OECD Countries: The Importance of Domestic Veto Players. Comparative Political Studies 31 (3):321-352.

Henisz, Witold Jerzy. 2000. The Institutional Environment for Economic Growth. Economics and Politics 12 (1):1-31.

Henisz, Witold Jerzy. 2004. Political Institutions and Policy Volatility. Economics and Politics $16(1): 1-27$.

Hiscox, Michael J., and Scott L. Kastner. 2002. A General Measure of Trade Policy Orientations: Gravity-Model-Based Estimates for 82 Nations 1960-92. Department of Government, Harvard University.

Hughes, Helen, and Jean Waelbroeck. 1981. Can Developing-Country Exports Keep Growing in the 1980s? World Economy 4:127-147.

Huntington, Samuel, P. 1991. The Third Wave: Democratization in the Late Twentieth Century. Norman, OK: University of Oklahoma Press.

Ikenberry, G. John, David A. Lake, and Michael Mastanduno. 1988. Introduction: Approaches to Explaining American Foreign Policy. International Organization 42 (1):59-90.

Ingram, Paul, Jeffrey Robinson, and Marc Busch. 2003. The Intergovernmental Network of World Trade: IGO Connectedness, Governance and Embeddedness.

Jaggers, Keith, and Ted Robert Gurr. 1995. Tracking Democracy's Third Wave with the Regime Type III Data. Journal of Peace Research 32 (November):469-482.

Kinder, Donald R., and D. Roderick Kiewiet. 1981. Sociotropic Politics: The American Case. British Journal of Political Science 11 (2):129-161.

Krueger, Anne O. 1993. Political Economy of Policy Reform in the Developing Countries. Cambridge, Mass.: MIT Press. 
Leamer, Edward E. 1988. Measures of Openness. In Trade Policy Issues and Empirical Analysis, edited by Robert E. Baldwin. Chicago: University of Chicago Press.

Lederman, Daniel. 2001. The Political Economy of Protection: Theory and the Chilean Experience. Washington, DC: World Bank.

Lewis-Beck, Michael S. 1988. Economic and Elections: The Major Western Democracies. Ann Arbor: University of Michigan Press.

Lohmann, Susanne, and Sharyn O'Halloran. 1994. Divided Government and U.S. Trade Policy: Theory and Evidence. International Organization 48 (4):595-632.

MacIntyre, Andrew. 2001. Institutions and Investors: The Politics of the Financial Crisis in Southeast Asia. International Organization 55 (1):81-122.

Magee, Stephen P., William A. Brock, and Leslie Young. 1989. Black Hole Tariffs and Endogenous Policy Theory. New York: Cambridge University Press.

Mansfield, Edward D., and Marc L. Busch. 1995. The Political Economy of Nontariff Barriers: A Cross-National Analysis. International Organization 49 (4):723-749.

Mansfield, Edward D., Helen V. Milner, and B. Peter Rosendorff. 2000. Free to Trade: Democracies, Autocracies and International Trade. American Political Science Review 94 (2):305-321.

Mansfield, Edward D., Helen V. Milner, and B. Peter Rosendorff. 2002. Why Democracies Cooperate More: Electoral Control and International Trade Agreements. International Organization 56 (3):477-513.

Marshall, Monty, and Keith Jaggers. 2001. Polity IV. Integrated Network for Societal Conflict Research (INSCR) Program, Center for International Development and Conflict Management, University of Maryland.

McCubbins, Matthew D., Roger G. Noll, and Barry R. Weingast. 1987. Administrative Procedures as Instruments of Political Control. Journal of Law, Economics and Organization 3 (2):243-277.

McCubbins, Matthew D., Roger G. Noll, and Barry R. Weingast. 1989. Structure and Process, Politics and Policy: Administrative Arrangements and the Political Control of Agencies. Virginia Law Review 75:431-482.

Milner, Helen V. 1997. Interests, Institutions, and Information: Domestic Politics and International Relations. Princeton, NJ: Princeton University Press.

Milner, Helen V., and Keiko Kubota. Forthcoming. Why the Rush to Free Trade? Democracy and Trade Liberalization in the LDCs. International Organization.

Nogues, Julio, and Sunil Gulati. 1994. Economic Policies and Performance Under Alternative Trade Regimes: Latin America During the 1980s. World Economy 17 (4):467-496.

Nowzad, Bahram. 1978. The Rise of Protectionism. Vol. 24, Pamphlet Series. Washington, DC: International Monetary Fund.

Olson, Mancur. 1983. The Political Economy of Comparative Growth Rates. In The Political Economy of Growth, edited by Dennis Mueller. New Haven: Yale University Press.

O'Rourke, Kevin, and Jeffrey G. Williamson. 1999. Globalization and History: The Evolution of a Nineteenth-Century Atlantic Economy. Cambridge, MA: MIT Press.

Przeworski, Adam, Michael E. Alvarez, Jose Cheibub, and Fernando Limongi. 2000. Democracy and Development: Political Institutions and Well-Being in the World, 1950-1990. Cambridge: Cambridge University Press.

Rodrik, Dani. 1996. Understanding Economic Policy Reform. Journal of Economic Literature, 34 (1): 9-41 
Rose, Andrew K. 2004a. Do We Really Know That the WTO Increases Trade? American Economic Review 94 (1):98-114.

Rose, Andrew K. 2004b. Does the WTO Make Trade More Stable? National Bureau for Economic Research Working Paper 10207.

Rose, Andrew K. 2004c. Which International Institutions Promote International Trade? Review of International Economics Forthcoming.

Saez, Sebastian, Juan Salazar, and Ricardo Vicuña. 1995. Antecedentes y resultados de la estrategia comercial del Gobierno Aylwin. Colección de Estudios CIEPLAN 40 (1):4166.

Schattschneider, Elmer E. 1935. Politics, Pressures and the Tariff: A Study of Free Private Enterprise in Pressure Politics, as Shown in the 1929-1930 Revision of the Tariff. New York: Prentice-Hall.

Schumpeter, Joseph. 1942. Capitalism, Socialism and Democracy. London: G. Allen \& Unwin Ltd.

Shapiro, Robert Y., and Benjamin I. Page. 1994. Foreign Policy and Public Opinion. In The New Politics of American Foreign Policy, edited by David A. Deese. New York: St. Martin's Press.

Subramanian, Avind, and Shang-Jin Wei. 2003. The WTO Promotes Trade, Strongly but Unevenly. National Bureau for Economic Research Working Paper 10024.

Treisman, Daniel. 2000. Decentralization and Inflation: Commitment, Collective Action or Continuity. American Political Science Review 94 (4):837-857.

Tsebelis, George. 1995. Decision-Making in Political Systems: Veto Players in Presidentialism, Parliamentarism, Multicameralism and Multipartyism. British Journal of Political Science 25 (3):289-325.

Tsebelis, George. 2003. Veto Players: How Political Institutions Work. Princeton, NJ: Princeton University Press.

Wacziarg, Romain, and Karen Horn Welch. 2003. Trade Liberalization and Growth: New Evidence. National Bureau for Economic Research Working Paper 10152.

Wade, Robert. 1990. Governing the Market: Economic Theory and the Role of the Government in East Asian Industrialization. Princeton, NJ: Princeton University Press.

Wallerstein, Michael. 1987. Unemployment, Collective Bargaining, and the Demand for Protection. American Journal of Political Science 31 (4):729-752.

Weingast, Barry, and Mark Moran. 1983. Bureaucratic Discretion or Congressional Control? Regulatory Policymaking by the Federal Trade Commission. Journal of Political Economy 91 (5):765-800.

Wintrobe, Ronald. 1998. The Political Economy of Dictatorship. New York: Cambridge University Press.

Wise, Carol. 1989. Democratization, Crisis, and the APRA's Modernization Project in Peru. In Debt and Democracy in Latin America, edited by Barbara Stallings and Robert Kaufman. Boulder, Colo.: Westview. 


\section{DAVIDSON INSTITUTE WORKING PAPER SERIES - Most Recent Papers}

The entire Working Paper Series may be downloaded free of charge at: www.wdi.bus.umich.edu

CURRENT AS OF 7/21/04

\begin{tabular}{|c|c|c|}
\hline Publication & Authors & Date \\
\hline $\begin{array}{l}\text { No. 712: Votes and Vetoes: The Political Determinants of Commercial } \\
\text { Openness }\end{array}$ & $\begin{array}{l}\text { Witold J. Henisz and Edward D. } \\
\text { Mansfield }\end{array}$ & July 2004 \\
\hline $\begin{array}{l}\text { No. 711: Interest Groups, Veto Points and Electricity Infrastructure } \\
\text { Deployment }\end{array}$ & $\begin{array}{l}\text { Witold J. Henisz and Bennet A. } \\
\text { Zelner }\end{array}$ & July 2004 \\
\hline $\begin{array}{l}\text { No. 710: Firms' Price Markups and Returns to Scale in Imperfect } \\
\text { Markets: Bulgaria and Hungary }\end{array}$ & $\begin{array}{l}\text { Rumen Dobrinsky, Gábor Körösi, } \\
\text { Nikolay Markov, and László } \\
\text { Halpern }\end{array}$ & July 2004 \\
\hline $\begin{array}{l}\text { No. 709: The Stability and Growth Pact from the Perspective } \\
\text { of the New Member States }\end{array}$ & Gábor Orbán and György Szapáry & July 2004 \\
\hline $\begin{array}{l}\text { No. 708: Contract Violations, Neighborhood Effects, and Wage Arrears } \\
\text { in Russia }\end{array}$ & $\begin{array}{l}\text { John S. Earle and Klara } \\
\text { Sabirianova Peter }\end{array}$ & July 2004 \\
\hline $\begin{array}{l}\text { No. 707: Determinants of Employment Growth at MNEs: Evidence } \\
\text { from Egypt, India, South Africa and Vietnam }\end{array}$ & $\begin{array}{l}\text { Sumon Kumar Bhaumik, Saul } \\
\text { Estrin and Klaus Meyer }\end{array}$ & July 2004 \\
\hline $\begin{array}{l}\text { No. 706: Economic Reform in Tanzania and Vietnam: A Comparative } \\
\text { Commentary }\end{array}$ & $\begin{array}{l}\text { Brian Van Arkadie and Do Duc } \\
\text { Dinh }\end{array}$ & June 2004 \\
\hline $\begin{array}{l}\text { No. 705: Beliefs about Exchange-Rate Stability: Survey Evidence } \\
\text { from the Currency Board in Bulgaria }\end{array}$ & $\begin{array}{l}\text { Neven T. Valev and John A. } \\
\text { Carlson }\end{array}$ & June 2004 \\
\hline No. 704: Returns to Schooling in China Under Planning and Reform & $\begin{array}{l}\text { Belton M. Fleisher and Xiaojun } \\
\text { Wang }\end{array}$ & June 2004 \\
\hline $\begin{array}{l}\text { No. 703: Return to Skills and the Speed of Reforms: Evidence from } \\
\text { Central and Eastern Europe, China and Russia }\end{array}$ & $\begin{array}{l}\text { Belton M. Fleisher, Klara } \\
\text { Sabirianova Peter, and Xiaojun } \\
\text { Wang }\end{array}$ & June 2004 \\
\hline $\begin{array}{l}\text { No. 702: What Makes Small Firms Grow? Finance, Human Capital, } \\
\text { Technical Assistance, and the Business Environment in Romania }\end{array}$ & $\begin{array}{l}\text { J. David Brown, John S. Earle } \\
\text { and Dana Lup }\end{array}$ & May 2004 \\
\hline $\begin{array}{l}\text { No. 701: The Effects of Multiple Minimum Wages Throughout the } \\
\text { Labor Market }\end{array}$ & $\begin{array}{l}\text { T. H. Gindling and Katherine } \\
\text { Terrell }\end{array}$ & May 2004 \\
\hline No. 700: Minimum Wages, Inequality and Globalization & $\begin{array}{l}\text { T. H. Gindling and Katherine } \\
\text { Terrell }\end{array}$ & May 2004 \\
\hline No. 699: Self-Selection and Earnings During Volatile Transition & Ralitza Dimova and Ira Gang & May 2004 \\
\hline No. 698: Ecology and Violence: The Environmental Dimensions of War & $\begin{array}{l}\text { Timothy L. Fort and Cindy A. } \\
\text { Schipani }\end{array}$ & May 2004 \\
\hline $\begin{array}{l}\text { No. 697: Russian Cities in Transition: The Impact of Market Forces in } \\
\text { the 1990s }\end{array}$ & Ira N. Gang and Robert C. Stuart & May 2004 \\
\hline $\begin{array}{l}\text { No. 696: Firm Ownership and Internal Labor Practices in a Transition } \\
\text { Economy: An Exploration of Worker Skill Acquisition in Vietnam }\end{array}$ & Jed Friedman & May 2004 \\
\hline No. 695: The Unanticipated Effects of Insider Trading Regulation & $\begin{array}{l}\text { Art A. Durnev and Amrita S. } \\
\text { Nain }\end{array}$ & May 2004 \\
\hline $\begin{array}{l}\text { No. 694: Volatile Interest Rates, Volatile Crime Rates: A New } \\
\text { Argument for Interest Rate Smoothing }\end{array}$ & Garett Jones and Ali M. Kutan & May 2004 \\
\hline $\begin{array}{l}\text { No. } 693 \text { Money Market Liquidity under Currency Board - Empirical } \\
\text { Investigations for Bulgaria }\end{array}$ & $\begin{array}{l}\text { Petar Chobanov and Nikolay } \\
\text { Nenovsky }\end{array}$ & May 2004 \\
\hline $\begin{array}{l}\text { No. 692: Credibility and Adjustment: Gold Standards Versus Currency } \\
\text { Boards }\end{array}$ & $\begin{array}{l}\text { Jean Baptiste Desquilbet and } \\
\text { Nikolay Nenovsky }\end{array}$ & May 2004 \\
\hline $\begin{array}{l}\text { No. 691: Impact of Cross-listing on Local Stock Returns: Case of } \\
\text { Russian ADRs }\end{array}$ & Elena Smirnova & May 2004 \\
\hline $\begin{array}{l}\text { No. 690: Executive Compensation, Firm Performance, and State } \\
\text { Ownership in China:Evidence from New Panel Data }\end{array}$ & Takao Kato and Cheryl Long & May 2004 \\
\hline $\begin{array}{l}\text { No. 689: Diverging Paths: Transition in the Presence of the Informal } \\
\text { Sector }\end{array}$ & Maxim Bouev & May 2004 \\
\hline $\begin{array}{l}\text { No. 688: What Causes Bank Asset Substitution in Kazakhstan? } \\
\text { Explaining Dollarization in a Transition Economy }\end{array}$ & Sharon Eicher & May 2004 \\
\hline
\end{tabular}

